\title{
Demes of a Puerto Rican Fleabeetle, Alagoasa bicolor (L.), Differing in Mean Body Size and Foodplant Association ${ }^{1}$
}

\author{
Niilo Virkki and Iraida Zambrana ${ }^{2}$
}

\begin{abstract}
Size of the fleabeetle Alagoasa bicolor (L.) was determined measuring the living body weight and the length of the right wing in four separate demes: in Vega Alta, Vacía Talega (Loíza), El Faro (Fajardo), and Salinas. The first deme is associated with Aegiphila martinicensis Jacq., all others with Clerodendrum aculeatum (L.). The largest beetles occur in Vega Alta, the smallest in Vacía Talega, whereas those of El Faro and Salinas have similar sizes.

Beetles of all four demes accept both foodplants, but tend to prefer the one to which they are associated in nature. Karyotype is the same in all demes, and copulation restrictions do not occur. From these results it is inferred that genetical isolation has not taken place between the demes, although the population biology of the species certainly facilitates such a development.
\end{abstract}

\section{INTRODUCTION}

Alagoasa bicolor (L.) Bechyné is a fleabeetle of sedentary habits (17) with a distribution limited to the Greater Antilles (2). In the eastern half of Puerto Rico, this species has been collected routinely from the following sites (fig. 1):

1. At Salinas, Barrio Río Jueyes, the section La Poza has probably the most extensive growth of the foodplant Clerodendrum aculeatum (L.) Schlecht. (Verbenaceae) in Puerto Rico. The best collection site has been Rivera's farm just north of the railway and extending west from the entrance road to Las Ochenta. The habitat of the beetle is complicated by the varying humidity conditions along the approximately 6 ha range of the foodplant, some shrubs growing near to inundable flats or near the freshwater channels crossing the area, others on higher, drier, sandy and gravelly grounds. Among the latter shrubs there is one which is heavily and almost continually infested: the best source of $C$. aculeatum-associated $A$. bicolor in Puerto Rico.

The property is used as pasture for cattle. Pasture management consists of an occasional bulldozing and burning of part of the vegetation. This obviously causes a massive death of preadult stages, and gallery effects on the remaining C. aculeatum by the surviving adults. Such refugia abound, and because the destroyed $C$. aculeatum rapidly recovers from roots, and even proliferates due to elimination of shade trees, the original

'Manuscript submitted to Editorial Board July 9, 1979.

${ }^{2}$ Cytogeneticist, Agricultural Experiment Station, Mayagüez Campus, University of Puerto Rico, Río Piedras, P.R. 00928; and third year student, University Garden High School, Río Piedras, P.R. 


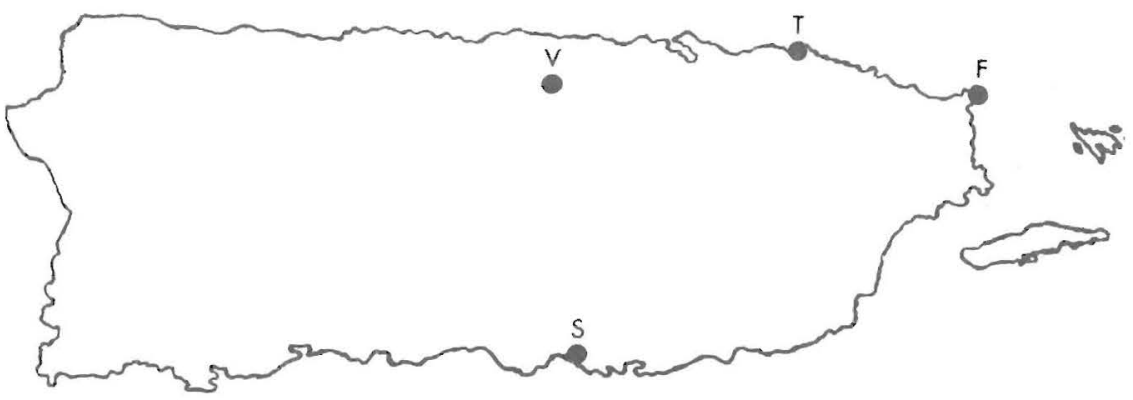

FIg. 1.-Location of the four Alagoasa bicolor demes studied. $\mathrm{V}=$ Vega Alta, $\mathrm{T}=$ Vacía Talega, $\mathrm{F}=$ El Faro, $\mathrm{S}=$ Salinas.

or increased growth is soon restored. Its reinvasion by the rather sedentary $A$. bicolor might be a retracted process, and this is perhaps one of the reasons why the foodplant range is found very unevenly infested (17).

2. El Faro farm (Fajardo) in the NE corner of the island contains a small, compact $C$. aculeatum growth at the eastern shore, only a few meters from the sea and separated from it by some unusually tall Coccoloba uvifera L. trees. The foliage, continuously swept by moist winds from the sea, is infested almost all the year round by A. bicolor. Obviously, this habitat is much simpler than the former one.

3. In Vacía Talega there is a small C. aculeatum growth on a relatively narrow sand bar between the sea and the mangrove. This habitat is believed to be marginal and only intermittently occupied. Until 1969 it was found empty, but it was artificially infested in July 15, 1969, by a release of $42 \mathrm{~A}$. bicolor specimens collected from Playa de Salinas (17); since that time, there has been a small deme.

4. In Vega Alta, the species lives far from the sea on the Verbenacean shrub Aegiphila martinicensis Jacq., which grows at the edges of a flat forest lot surrounded by pineapple fields. The soil (Almirante series, an Oxisols) is much richer than in the other sites, and similar throughout the site. The region receives abundant rainfall (about $1650 \mathrm{~mm}$ per year). Scattered specimens of an introduced ornamental, Clerodendrum speciossimum Paxt., are also attacked.

Visual observation of the $A$. bicolor harvests from these sites suggested size differences among the beetles. Specimens from Vega Alta looked constantly larger than the others, and those of Vacía Talega seemed the smallest. The present study is an attempt to quantify these differences more exactly. Foodplant preferences will be studied also.

\section{MATERLALS AND METHODS}

The beetles were collected, transported, stored overnight, and sexed as before (17). Mean living body weight was determined by weighing sexed 
and narcotized samples and by dividing the bulk weight thus obtained by the number of individuals. Since this procedure is influenced by the ovarial development in the female, and does not permit analysis of variation, Suzuki's (14) method of comparison of the length of the right wing was also used. The wings were soaked in $70 \%$ alcohol and spread well in rows on clean object glasses, and left to dry. When completely dry, they were sealed in Damar balsam, using $22 \times 50 \mathrm{~mm}$ coverslips. Measures (fig. 2A) were taken with a 6x Edscorp pocket comparator provided with a scale of $0.1 \mathrm{~mm}$ accuracy. Photographs were obtained by projecting the preparations on a photographic paper in an enlarger.

Designing food preference tests is not easy. In the experimental area
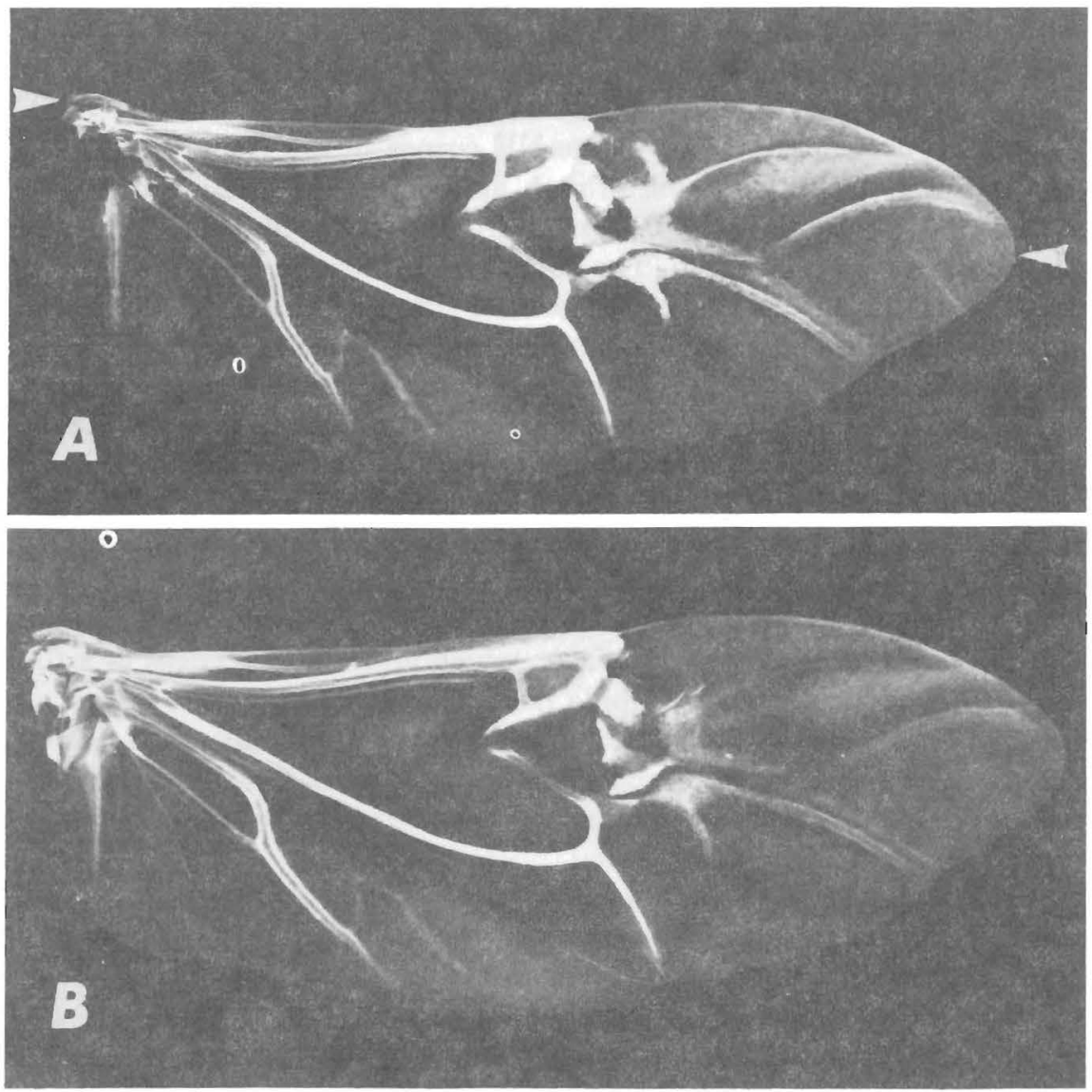

FIG. 2.-Alagoasa bicolor. Male (A) and female (B) right wing from Salinas. Arrowheads in A show the points between which the length was measured. Negative pictures projected directly from the preparations in an enlarger. 16x. 
beetles moving at random may more frequently land on $A$. martinicensis leaves, because they are 4-5 times larger in area than $C$. aculeatum leaves. If leaves of similar size are offered, $A$. martinicensis leaves will most probably be young and preferred for this reason (17). If the humidity preferred by $A$. bicolor in nature (under 68\%: 17) is maintained, the leaves will wilt in about four hours at our laboratory temperature (about $25^{\circ} \mathrm{C}$ ), and sooner if leaf discs (8) are used. During this time, beetles brought directly from the field may not eat at all. Attempts to use leaves whose stalks were kept in water produced very confusing results, probably due to the different ratio intake/evaporation of water in the two species of leaves.

The first tests were based on eaten areas. Because the $A$. martinicensis leaves seem thinner than $C$. aculeatum leaves, comparison of areas was later replaced by comparison of weights consumed. The final design adopted was as follows:

Beetles starved for 72 hours in clean plastic bags at $25^{\circ} \mathrm{C}$ were sexed and placed in petri dishes, 12 of the same sex in each, together with one A. martinicensis leaf and one or two C. aculeatum leaves. Young leaves of about the same age were used. The illumination was the same used by Virkki (17) in earlier feeding tests. The exposure lasted for 3 hours. Similar control leaves were simultaneously kept in petri dishes without beetles. All leaves were weighed before and after the experiment. Percentage loss by evaporation during the experiment was determined for the control leaves. A corresponding percentage was subtracted from the initial weight of the exposed leaves, and only after that, the final weight was subtracted. The weight loss by evaporation of the eaten proportion was ignored. A few representative leaves are illustrated using the same method as before (17), with the only difference that Letraset Protection Coating Aerosol was used as an adhesive this time.

To check readiness for copulation, females found in copula in the field were separated and enclosed for 24 hours in petri dishes, each one with an allodemic male. Females collected in a non-copulating state seldom copulate in these experiments, probably because young virgins and mated females are unattractive to males (9).

\section{RESULTS AND DISCUSSIONS}

The visual observations made during the collection were confirmed: Vacía Talega (T) has the smallest, Vega Alta (V) the largest beetles (table 1 and fig. 3). Salinas (S) and El Faro (F) materials fall in between and do not differ much from one another, despite the difference of complexity of their niches. The length of the right wing does not differ significantly between beetles of these two demes, but in most cases the wing length differences are statistically significant as indicated by the 
TABLE 1.-Living body weights (mg) in four demes of Alagoasa bicolor

\begin{tabular}{|c|c|c|c|c|c|c|c|c|c|c|c|c|c|c|c|c|}
\hline \multirow{3}{*}{ Date } & \multicolumn{8}{|c|}{ Females } & \multicolumn{8}{|c|}{ Males } \\
\hline & \multicolumn{2}{|c|}{ Salinas } & \multicolumn{2}{|c|}{$\begin{array}{l}\text { Vacía } \\
\text { Talega }\end{array}$} & \multicolumn{2}{|c|}{ El Faro } & \multicolumn{2}{|c|}{ Vega Alta } & \multicolumn{2}{|c|}{ Salinas } & \multicolumn{2}{|c|}{$\begin{array}{l}\text { Vacia } \\
\text { Talega }\end{array}$} & \multicolumn{2}{|c|}{ El Faro } & \multicolumn{2}{|c|}{ Vega Alta } \\
\hline & Mean & $\mathrm{n}$ & Mean & $\mathrm{n}$ & Mean & $\mathrm{n}$ & Mean & $\mathrm{n}$ & Mean & $\mathrm{n}$ & Mean & $\mathrm{n}$ & Mean & $\mathrm{n}$ & Mean & $\mathrm{n}$ \\
\hline 11.IV.77 & & & & & & & & & & & 12.3 & 4 & & & & \\
\hline 14.IV. & & & & & & & 32.4 & 20 & & & & & & & 20.6 & 16 \\
\hline & & & & 5 & & & 36.7 & 47 & & & & s & & & 23.4 & 41 \\
\hline $\begin{array}{l}25 . \mathrm{IV} \\
16 . \mathrm{V}\end{array}$ & 24.4 & 8 & 24.0 & 5 & & & & & 16.4 & 16 & 16.3 & 6 & & & & \\
\hline $6 . \mathrm{V}$ & & & & & & & & & 16.6 & 8 & & & & & & \\
\hline 8.VIII. & 28.1 & 7 & & & & & & & 16.0 & 3 & & & & & & \\
\hline 15.VIII. & 27.0 & 6 & & & & & & & 17.5 & 4 & & & & & & \\
\hline 22.VIII. & 28.5 & 10 & & & & & & & 15.0 & 6 & & & & & & \\
\hline 29.VIII. & 29.2 & 12 & & & & & 32.6 & 9 & 14.6 & 5 & & & & & 18.9 & 15 \\
\hline 19.IX & & & & & & & 27.8 & 30 & & & & & & & 16.9 & 16 \\
\hline $5 . \mathrm{X}$ & & & & & & & 26.6 & 14 & & & & & & & 18.1 & 12 \\
\hline $11 . \mathrm{X}$ & & & & & 32.0 & 9 & & & & & & & 19.1 & 7 & & \\
\hline 17.X. & 23.1 & 9 & & & & & & & 16.4 & 5 & & & & & & \\
\hline 14.XI. & 27.2 & 10 & & & & & & & 19.8 & 20 & & & & & & \\
\hline 20.XI. & 30.3 & 44 & & & & & & & 17.2 & 59 & & & & & & \\
\hline 21.XI. & & & 27.0 & 2 & & & & & & & 14.0 & 3 & & & & \\
\hline 22.XI. & & & & & 28.1 & 41 & & & & & & & 17.9 & 42 & & \\
\hline 28.XI. & & & 24.7 & 3 & & & & & & & 15.2 & 5 & & & & \\
\hline 9.I.78 & 27.0 & 26 & 29.8 & 4 & & & & & 18.0 & 33 & 15.2 & 5 & & & & \\
\hline 16.I. & & & 38.9 & 5 & & & & & & & 14.0 & 1 & & & & \\
\hline 23.I. & & & 23.5 & 6 & & & & & & & 16.3 & 3 & & & & \\
\hline 13.II. & & & 25.3 & 15 & & & & & & & 15.9 & 15 & & & & \\
\hline 21.II. & & & 19.8 & 6 & 24.7 & 11 & & & & & 9.8 & 4 & 20.9 & 26 & & \\
\hline 27.II. & & & 25.4 & 8 & & & & & & & 16.0 & 3 & & & & \\
\hline 6.III. & & & 23.2 & 9 & & & & & & & 14.6 & 7 & & & & \\
\hline 13.III. & & & 25.5 & 9 & & & & & & & 15.0 & 5 & & & & \\
\hline 20.III. & & & 24.9 & 14 & & & & & & & 15.3 & 14 & & & & \\
\hline 27.III. & & & 28.3 & 11 & & & & & & & 15.8 & 11 & & & & \\
\hline 3.IV. & & & 27.0 & 8 & & & & & & & 15.3 & 7 & & & & \\
\hline 10.IV. & & & 22.5 & 11 & 27.5 & 21 & & & & & 14.1 & 9 & 17.4 & 48 & & \\
\hline 18.IV. & & & 24.7 & 10 & & & & & & & 15.1 & 9 & & & & \\
\hline 24.IV. & & & & & 28.1 & 7 & & & & & & & 17.7 & 20 & & \\
\hline & 28.1 & 132 & 25.4 & 126 & 27.9 & 89 & 32.3 & 120 & 17.4 & 159 & 15.0 & 111 & 18.3 & 143 & 20.6 & 100 \\
\hline
\end{tabular}


following $t$ values:

\begin{tabular}{lcl} 
& Females & \multicolumn{1}{c}{ Males } \\
S vs. T & $2.57^{\mathrm{x}}$ & $4.55^{\mathrm{xx}}$ \\
S vs. V & $5.55^{\mathrm{xx}}$ & $6.05^{\mathrm{xx}}$ \\
F vs. V & $5.44^{\mathrm{xx}}$ & $5.43^{\mathrm{xx}}$ \\
T vs. F & $2.65^{\mathrm{x}}$ & $5.25^{\mathrm{xx}}$ \\
T vs. V & $8.30^{\mathrm{xx}}$ & $10.74^{\mathrm{xx}}$
\end{tabular}

Tables 1 and 2 give an idea of the sample size that can be expected from the different sites. The number of host shrubs per site is less important than it might seem. In the complex Salinas habitat, the shrubs are quite selectively infested, whereas the more compact, homogenous Cloredendrum or Aegiphila growths of the other sites are evenly attacked. The small Vacía Talega site appears as a poor source of $A$. bicolor. Obviously, the introduced deme lives there in a difficult niche, under a continuous threat of extinction.

El Faro area seems to be the best source for the Clerodendrumassociated $A$. bicolor (the best individual host shrub, however, occurs in Salinas; see Introduction). At Vega Alta, the only Aegiphila-associated deme studied, is comparable to that of El Faro.

The sample size fluctuates due to unknown factors, among which might be rainfall. Thus, in 1969, $30.9 \mathrm{~A}$. bicolor specimens per excursion were collected from two C. aculeatum bushes in the now destroyed Playa de Salinas site. In 1971, the same bushes produced only 3.9 beetles per excursion (17). These two bushes growing on an open ground were well exposed to the spells of the relatively dry South Coast climate. Most shrubs of the present Salinas site are better shielded, although only a few might be considered as safe hosts. The site at Vega Alta, with its rich soil and abundant rain, and that at El Faro, with a continuous moist wind, offer the stablest environment where the fluctuation of infestation is at a minimum.

The females are definitely larger than the males (figs. 2 and 3) and usually eat more (tables 3 to 6 ). Calculated for the whole material, the mean living body weight is $28.4 \mathrm{mg}$ for the females, and $17.8 \mathrm{mg}$ for the males. The right wings measure $70.86 \pm 0.01 \mathrm{~mm}$ and $70.02 \pm 0.02 \mathrm{~mm}$, respectively. Contrary to a smaller material collected earlier in Playa de Salinas (17), males were now more often caught than females: 467 oq vs. 513 ơ; the difference is significant statistically.

Gravid females are plump and heavier than non-gravid ones. Because there is no special time of the year when female weights would appear larger (table 1), it can be inferred that, as a rule, individuals of different age occur simultaneously and in little changing proportions in the demes. 


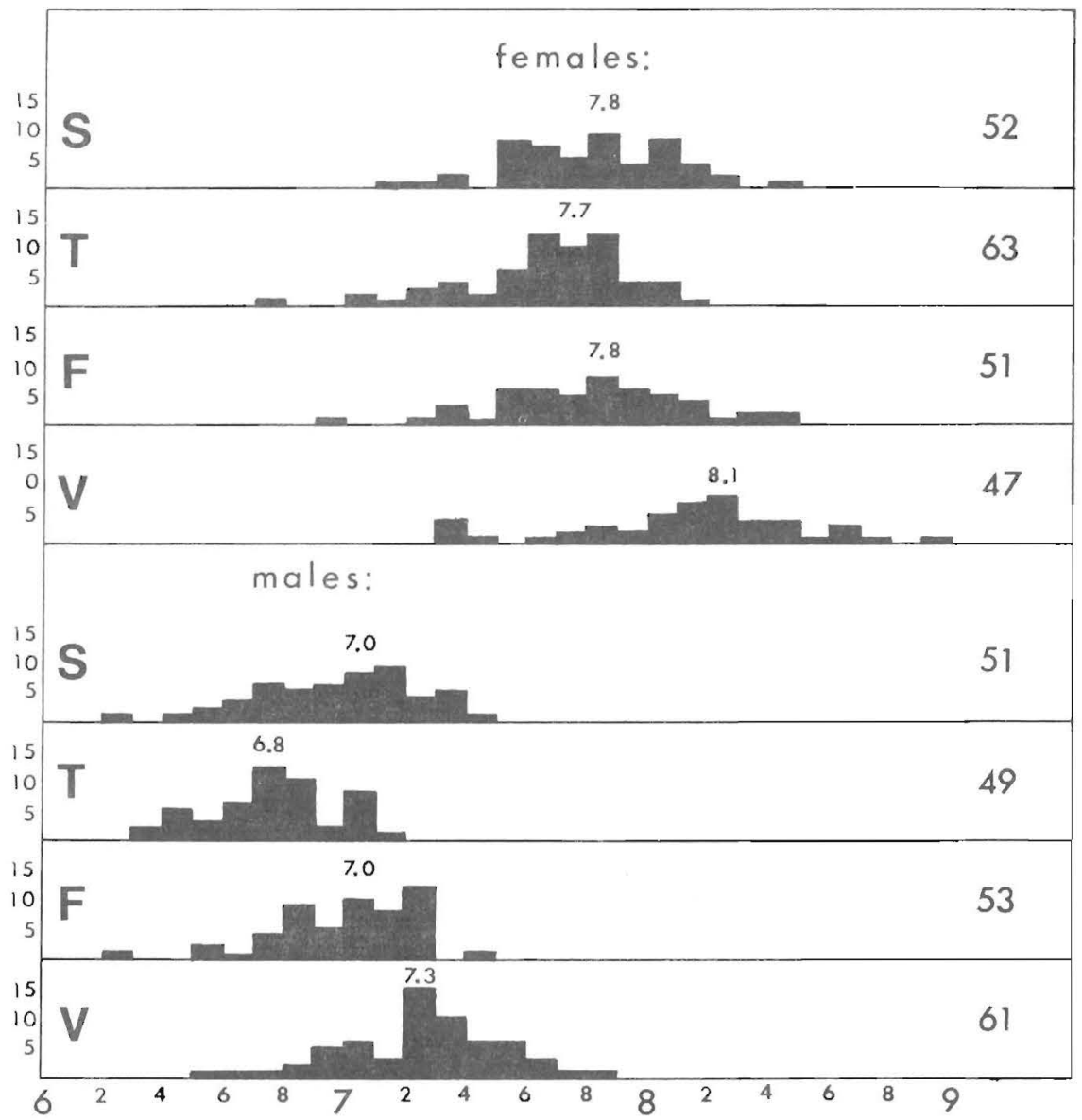

Frg. 3.-Alagoasa bicolor. Length $(\mathrm{mm})$ of the right wing in the materials of Salinas (S), Vacía Talega (T), El Faro (F), and Vega Alta (V). Mean length for each deme on the top of the curve. Horizontal axis: 6 to $9 \mathrm{~mm}$, with even decimals; vertical axis: number of individuals. To the right, total number of individuals measured.

TABLE 2.-Mean number of Alagoasa bicolor specimens collected per excursion

\begin{tabular}{lccrc}
\hline \multicolumn{1}{c}{ Site } & No. of shrubs $^{1}$ & Females & Males & Both sexes \\
\hline Salinas & 200 & 14.7 & 15.9 & 29.1 \\
Vacía Talega & 10 & 7.9 & 6.5 & 13.9 \\
El Faro & 20 & 17.8 & 28.6 & 46.4 \\
Vega Alta & 30 & 24.0 & 20.0 & 44.0 \\
\hline
\end{tabular}

${ }^{1}$ A rough estimation.

This observation is somewhat weakened by the discontinuity of the present collection series, and by earlier observations on population peaks and development of ovarioles (18). Sometimes the mean weights vary similarly in both sexes collected the same day (see the Vega Alta series, 
TABLE 3.-Food preference of Aegiphila-associated Alagoasa bicolor; Areas $\left(\mathrm{mm}^{2}\right)$ of consumed amounts of Aegiphila martinicensis and Clerodendrum aculeatum leaves during 3 hours by 8 samples of 12 beetles previously starved for 44 hours

\begin{tabular}{lccccc}
\hline \multirow{2}{*}{ Date of exposure } & \multicolumn{2}{c}{ Females } & & \multicolumn{2}{c}{ Males } \\
\cline { 2 - 3 } \cline { 5 - 6 } & Aegiphila & Clerodendrum & & Aegiphila & Clerodendrum \\
\hline 8.IX.78 & 51.9 & 46.8 & & 30.3 & 27.1 \\
13.IX.78 & 92.4 & 94.7 & & 40.2 & 13.3 \\
20.IX.78 & 99.5 & 45.4 & & 129.3 & 16.2 \\
20.II.78 & 127.2 & 82.0 & & 40.0 & 0.2 \\
Total consumed & 371.0 & 269.0 & & 239.0 & 56.8 \\
mm $^{2}$ /specimen & 7.73 & 5.60 & & 4.98 & 1.18 \\
\hline
\end{tabular}

TABLE 4.-Food preference of Clerodendrum-associated Alagoasa bicolor: Areas $\left(\mathrm{mm}^{2}\right)$ of consumed amounts of Aegiphila martinicensis and Clerodendrum aculeatum leaves during 3 hours by 8 samples of 12 beetles previously starved for 44 hours

\begin{tabular}{lcccrc}
\hline \multirow{2}{*}{ Date of exposure } & \multicolumn{2}{c}{ Females } & & \multicolumn{2}{c}{ Males } \\
\cline { 2 - 3 } \cline { 5 - 6 } & Aegiphila & Clerodendrum & & Aegiphila & Clerodendrum \\
\hline 8.IX.78 & 63.5 & 73.3 & & 35.3 & 5.8 \\
13.IX.78 & 48.3 & 47.4 & & 3.0 & 20.8 \\
20.IX.78 & 17.5 & 17.0 & & 2.2 & 42.0 \\
20.II.79 & 4.5 & 24.0 & & 10.0 & 0.5 \\
Total consumed & 133.8 & 161.7 & & 50.5 & 69.1 \\
$\mathrm{~mm}^{2} /$ specimen & 2.79 & 3.37 & & 1.05 & 1.44 \\
\hline
\end{tabular}

TABLE 5.-Food preference of Aegiphila-associated Alagoasa bicolor: Weights ( $m g$ ) of consumed amounts of Aegiphila martinicensis and Clerodendrum aculeatum leaves during 3 hours by 9 samples of 12 beetles previously starved for 72 hours

\begin{tabular}{|c|c|c|c|c|}
\hline \multirow{2}{*}{$\begin{array}{l}\text { Date, hours, temperature, and } \\
\text { humidity }\end{array}$} & \multicolumn{2}{|c|}{ Females } & \multicolumn{2}{|c|}{ Males } \\
\hline & Aegiphila & Clerodendrum & Aegiphila & Clerodendrum \\
\hline $\begin{array}{l}\text { 8.VI.78 } \\
8: 30-11: 30 \\
27.5^{\circ} \mathrm{C}, 63 \%\end{array}$ & & & 21 & 14 \\
\hline $\begin{array}{l}\text { 15.VI.78 } \\
9: 30-11: 30 \\
25.3^{\circ} \mathrm{C}, 62.5 \%\end{array}$ & $\begin{array}{l}17 \\
28\end{array}$ & $\begin{array}{l}8 \\
4\end{array}$ & $\begin{array}{l}29 \\
48\end{array}$ & $\begin{array}{r}14 \\
5\end{array}$ \\
\hline $\begin{array}{l}22 . \text { VI.78 } \\
16: 30-19: 30 \\
26.3^{\circ} \mathrm{C}, 64 \%\end{array}$ & $\begin{array}{l}21 \\
38\end{array}$ & $\begin{array}{l}0 \\
0\end{array}$ & $\begin{array}{l}21 \\
31\end{array}$ & $\begin{array}{l}0 \\
3\end{array}$ \\
\hline Total consumed & 104 & 12 & 150 & 36 \\
\hline $\mathrm{mg} /$ specimen & $2.17^{1}$ & $0.25^{1}$ & $2.50^{2}$ & $0.60^{2}$ \\
\hline
\end{tabular}


TABLE 6.-Food preference of Clerodendrum-associated Alagoasa bicolor: Weights (mg) of consumed amounts of Aegiphila martinicensis and Clerodendrum aculeatum leaves during 3 hours by 6 samples of 12 beetles previously starved for 72 hours

\begin{tabular}{|c|c|c|c|c|}
\hline \multirow{2}{*}{$\begin{array}{l}\text { Date, hours, temperature, and } \\
\text { humidity }\end{array}$} & \multicolumn{2}{|c|}{ Females } & \multicolumn{2}{|c|}{ Males } \\
\hline & Aegiphila & Clerodendrum & Aegiphila & Clerodendrum \\
\hline 15.VI.78 & 15 & 40 & 20 & 20 \\
\hline $9: 30-11: 30$ & 3 & 17 & & \\
\hline \multicolumn{5}{|l|}{$25.3^{\circ} \mathrm{C}, 62.5 \%$} \\
\hline 22.VI. 78 & 28 & 0 & 7 & 0 \\
\hline $16: 30-19: 30$ & & & 10 & 0 \\
\hline \multicolumn{5}{|l|}{$26.3^{\circ} \mathrm{C}, 64 \%$} \\
\hline Total consumed & 46 & 57 & 37 & 20 \\
\hline mg/specimen & 1.28 & 1.58 & 1.03 & 0.56 \\
\hline
\end{tabular}

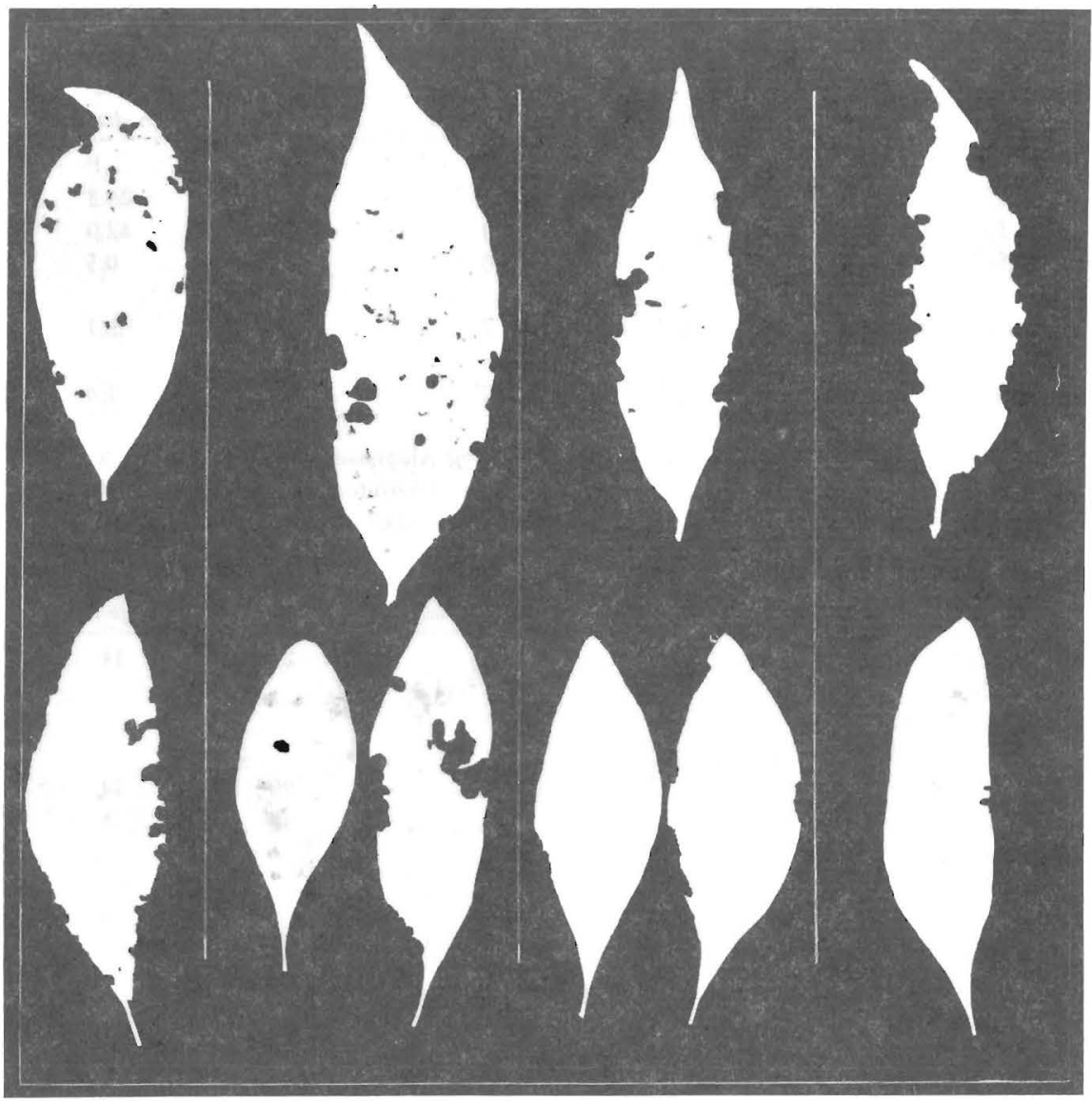

FIG. 4.-Alagoasa bicolor. Some results from the feeding preference tests. Aegiphila martinicensis leaves above, Clerodendrum aculeatum leaves below. First two tests from the left were performed with Salinas beetles, the following two with Vega Alta beetles. A contact copy. 
and Vacía Talega in 21.11.77: table 1). This could be due to similar environmental effects in even-aged specimens.

Whether the size differences are predominantly genetically or environmentally determined cannot be decided yet. In the insects, the adult size largely depends on the larval nutrition $(1,4-7,15)$. Thus the size differences might just reflect the quality of the habitats.

The feeding tests show that both host plants are accepted as food (tables 3-6, fig. 4). In the experiments there was a tendency to prefer the accustomed foodplant, although this tendency reached levels significant by $t$ test only in the experiment where weights eaten by the Vega Alta specimens were measured (table 5).

As such a preference can be learned during the life of an individual insect $(3,8,10)$, it does not serve as a reliable proof for a genetic differentiation between the demes. No isolating sexual behavior patterns have formed either, because copulation takes place between the Aegiphila- and Clerodendrum-associated individuals (19). Furthermore, the karyotype, C-bands inclusive, is similar in all demes (19).

On the other hand, the sedentary habits (17), the rather discontinuous distribution, and the small deme size favor a rapid genetical differentiation in this species. The large, non-chiasmate sex chromosomes may play an important role thereby (11). Starch gel electrophoresis $(12,13)$ seems the next best step to study the matter further.

\section{RESUMEN}

El tamaño del alticino Alagoasa bicolor (L.) fue determinado por medidas de peso vivo del cuerpo y del largo del ala derecha en cuatro demes diferentes unos de otros: en Vega Alta, Vacía Talega (Loíza), El Faro (Fajardo) y Salinas. El primer deme está asociado con Aegiphila martinicensis Jacq., todos los demás con Clerodendrum aculeatum (L.). Los escarabajos más grandes ocurren en Vega Alta, los más pequeños en Vacía Talega, mientras que en El Faro y Salinas los tamaños son similares.

Los escarabajos de las cuatro demes aceptan ambas plantas huéspedes, pero tienden a preferir la planta con que están asociados en la naturaleza. El cariotipo es igual en todas las demes, y no hay restricción en cuanto a la copulación. Se infiere de estos resultados que no ha ocurrido aislamiento genético entre las demes, aunque la biología poblacional de la especie lo facilite.

\section{LITERATURE CITED}

1. Benyi, K. and Gall, G. A. E., 1978. Genotype-environment interaction effects on growth and development in Tribolium castaneum, J. Hered. 69: 71-6.

2. Blackwelder, R. E., 1946. Checklist of the Coleopterous insects of Mexico, Central America, The West Indies, and South America, Smithson. Inst. U.S. Nat. Mus. Bull. 185(4): 551-763. 
3. Cassidy, M. D., 1978. Development of an induced foodplant preference in the Indian stick insect, Carasius morosus, Entomol. Exp. Appl. 24: 287-93.

4. Cibula, A. B., Davidson, R. H., Fisk, F. W., and La Pidus, J. B., 1967. Relationship of free amino acids of some solanaceous plants to growth and development of Leptinotarsa decemlineata (Coleoptera:Chrysomelidae), Ann. Entomol. Soc. Am. 60: 62631.

5. Feeny, P. P., 1968. Effect of oak leaf tannins on larval growth of the winter moth Operophtera brumata, J. Insect. Physiol. 14: 805-17.

6. House, H. L., 1963. Nutritional diseases, pp. 133-160 in: Stenhaus, E. A. (Ed), Insect Pathology I, Academic Press, New York.

7. - - 1965. Insect Nutrition, pp. 769-813 in: Rockstein, M. (Ed), The Physiology of Insecta, Academic Press, New York.

8. Jermy, T., Hanson, F. E., and Dethier, V. G., 1968. Induction of specific food preference in Lepidopterous larvae, Entomol. Exp. Appl. 11: 211-30.

9. Mathews, R. W. and Mathews, J. R., 1978. Insect Behavior, Wiley and Sons, New York.

10. McIndoo, N. E., 1935. The relative attractiveness of certain Solanaceous plants to the Colorado potato beetle, Leptinotarsa decemlineata Say, Proc. Entomol. Soc. Wash. 37: $35-42$.

11. Smith, S. G. and Virkki, N., 1978. Animal Cytogenetics: Coleoptera (B. John, Ed). Borntraeger, Berlin-Stuttgart.

12. Suomalainen, E. and Saura, A., 1973. Genetic polymorphism and evolution in parthenogenetic animals. I. Polyploid Curculionidae, Genetics 74: 489-508.

13. _- Saura, A., and Lokki, J., 1976. Evolution of parthenogenetic insects, Evol. Biol. 9: $209-57$.

14. Suzuki, K., 1975. Variation of ovariole number in Pseudodera xanthospila Baly (Coleoptera, Chrysomelidae, Alticinae), Kontyû 43: 36-9.

15. Trager, W., 1953. Nutrition, pp. 350-386 in: Roeder, K. D. (Ed), Insect Physiology, Wiley \& Sons, New York.

16. Virkki, N., 1979. Ovariole numbers in two Puerto Rican Oedionychina (Coleoptera), J. Agri. Univ. Puerto Rico 63: 50-6.

17. _- 1980. Fleabeetles, especially Oedionychina, of a Puerto Rican marshland in 196972, J. Agri. Univ. P.R. 64(1): 63-92.

18. - - 1979. Response of an Oedionychina (Coleoptera) karyotype to acute gamma radiation, J. Agri. Univ. Puerto Rico 63(2): 116 45.

19. - - Unpublished data. 